http://dx.doi.org/10.11646/phytotaxa.117.1.2

\title{
Taxonomic reexamination of Portulaca okinawensis (Portulacaceae) in the Ryukyu Archipelago of Japan based on molecular and morphological data
}

\author{
GORO KOKUBUGATA ${ }^{1 *}$, KOH NAKAMURA ${ }^{2}$, YUMIKO HIRAYAMA ${ }^{1} \&$ MASATSUGU YOKOTA $^{3}$ \\ ${ }^{\prime}$ Department of Botany, National Museum of Nature and Science, Tsukuba, Ibaraki 305-0005, Japan; e-mail: gkokubu@kahaku.go.jp \\ ${ }^{2}$ Biodiversity Research Center, Academia Sinica, Nangang, Taipei 115, Taiwan. \\ ${ }^{3}$ Laboratory of Ecology and Systematics, Faculty of Science, University of the Ryukyus, Senbaru 1, Nishihara, Okinawa 903-0213, \\ Japan. \\ author for correspondence
}

\begin{abstract}
We used molecular phylogenetic and morphological data to reexamine the taxonomic status of Portulaca okinawensis ( $\equiv$ P. pilosa subsp. okinawensis) endemic to the central Ryukyu islands, southwestern Japan. Our molecular analyses showed that $P$. okinawensis is monophyletic, sister to the clade of P. psammotropha and P. tuberosa and it is not closely related to $P$. pilosa subsp. pilosa. Two subclades, one comprising plants from the Okinawa Islands and the other from the Amami Islands, were recognized. The plants from the Okinawa Islands had more than 20 stamens, orange-yellow nallowly obovate to oblanceolate petals, and reddish-green stems (as the holotype), while the plants from the Amami Islands had less than 20 stamens, lemon-colored obovate petals, and bright-green stems. The molecular and morphological data support a taxonomic treatment of Walker \& Tawada (1951) regarding P. okinawensis as a separate species, also suggesting that the plants from the Amami and Okinawa islands should be treated as different taxa. A new variety Portulaca okinawensis var. amamiensis was here described.
\end{abstract}

Key words: ITS phylogeny, Japan, morphological data, new taxon, Portulaca pilosa, Ryukyu Islands

\section{Introduction}

Portulacaceae Juss. is a monotypic family including only Portulaca Linnaeus (1753: 445) (Nyffeler \& Eggli 2010). Portulaca includes over 100 species of annuals and perennials and is distributed worldwide (mostly in the tropics and subtropics) with the center of species diversity in South America and Africa (Ocampo \& Columbus 2012). The Ryukyu Archipelago (the Ryukyus) is located between the Kyushu Island (Japan) and Taiwan, and comprises about 140 islands (Fig. 1). Three native Portulaca species have been reported in the Ryukyus (Walker 1976, Shimabuku 1997): the pantropical P. oleracea Linnaeus (1753: 445) from most of the islands, $P$. quadrifida Linnaeus (1767: 328) distributed in tropical Asia and Africa but collected only once in Ikei-jima Island being an islet of the Okinawa Islands, and P. okinawensis Walker \& Tawada (1951: 138) [三 P. pilosa Linnaeus (1753:445) subsp. okinawensis (Walker \& Tawada) Geesink (1969: 298)]. P. okinawensis was described by Walker \& Tawada (1951) on a specimen collected from Okinawa Island. This taxon rarely occurs on coastal rocky slopes in the Amami Islands and the Okinawa Islands, and is a critically threatened species in a Japanese red list (Japanese Ministry of Environment 2012).

Portulaca okinawensis is considered to be endemic to the central Ryukyus that consisted of the Okinawa and Amami islands (Fig. 1; Hotta 2004, Shinjo \& Shinzato 2006). Geesink (1969) recognized P. okinawensis as subspecies of $P$. pilosa based on the leaf morphology. Portulaca pilosa subsp. pilosa is native to South America and widely naturalized in the tropics and subtropics (PIER 2013) including the Ryukyus (Hatusima 1975). The taxonomic concept of Walker \& Tawada (1951) was accepted by Momiyama (1982) and Akiyama 
(2006), while that of Geesink (1969) was accepted by Hatusima (1975) and Hatusima \& Amamo (1994). Here, we tentatively used the name $P$. okinawensis and later discuss its taxonomy and proper name based on our resultant phylogeny.

Aiming to clarify the taxonomic status of $P$. okinawensis, we carried out molecular phylogenetic analyses of nuclear ribosomal DNA (ITS). Furthermore, we studied intraspecific taxonomy of $P$. okinawensis based on a morphological approach and the ITS-sequence polymorphisms to properly understand the floristic biodiversity of the Ryukyus and to benefit conservation activities for this critically endangered species.

\section{Materials and Methods}

\section{Molecular analyses}

\section{DNA sample collection}

Samples of $P$. okinawensis from 12 localities (two samples per locality) in six central Ryukyus islands were collected and analyzed: Amami Island (4 localities) and Tokuno-shima Island (1) in Amami Islands; Okinawa Island (4), Geruma Island (1), Aka Island (1) and Tonaki Island (1) in Okinawa Islands (Fig. 1; Table 1). A collection locality in Onna of Okinawa Island (OK2 in Table 1 and Fig. 1) is the locus classicus of $P$. okinawensis.

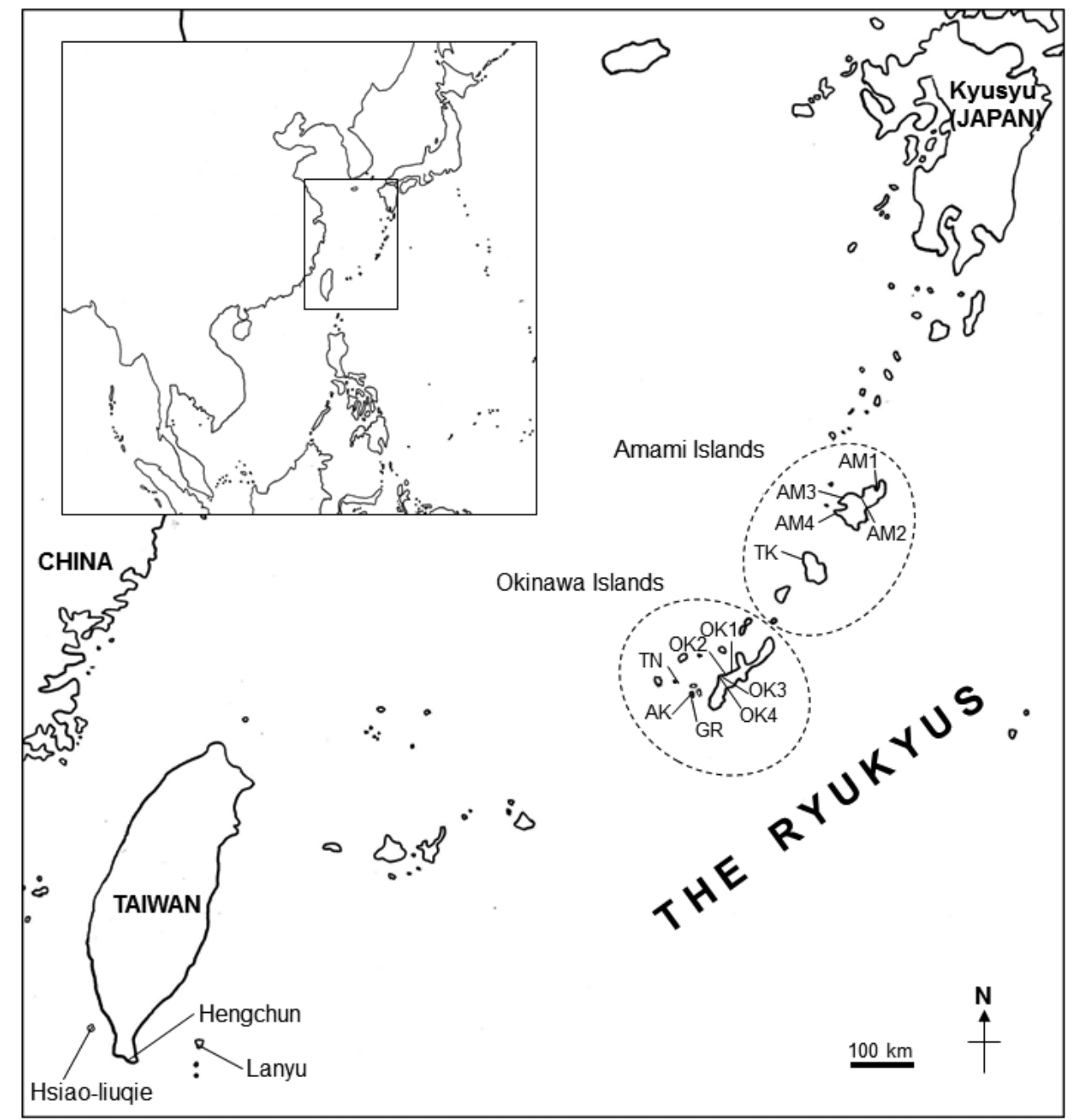

FIGURE 1. Map of the Ryukyus showing 12 localities on six islands of Portulaca okinawensis and four localities of P. psammotropha in Taiwan. Broken lines circle the islands of the Amami Islands and the Okinawa Islands (see Table 1 for abbreviations for collection localities). 


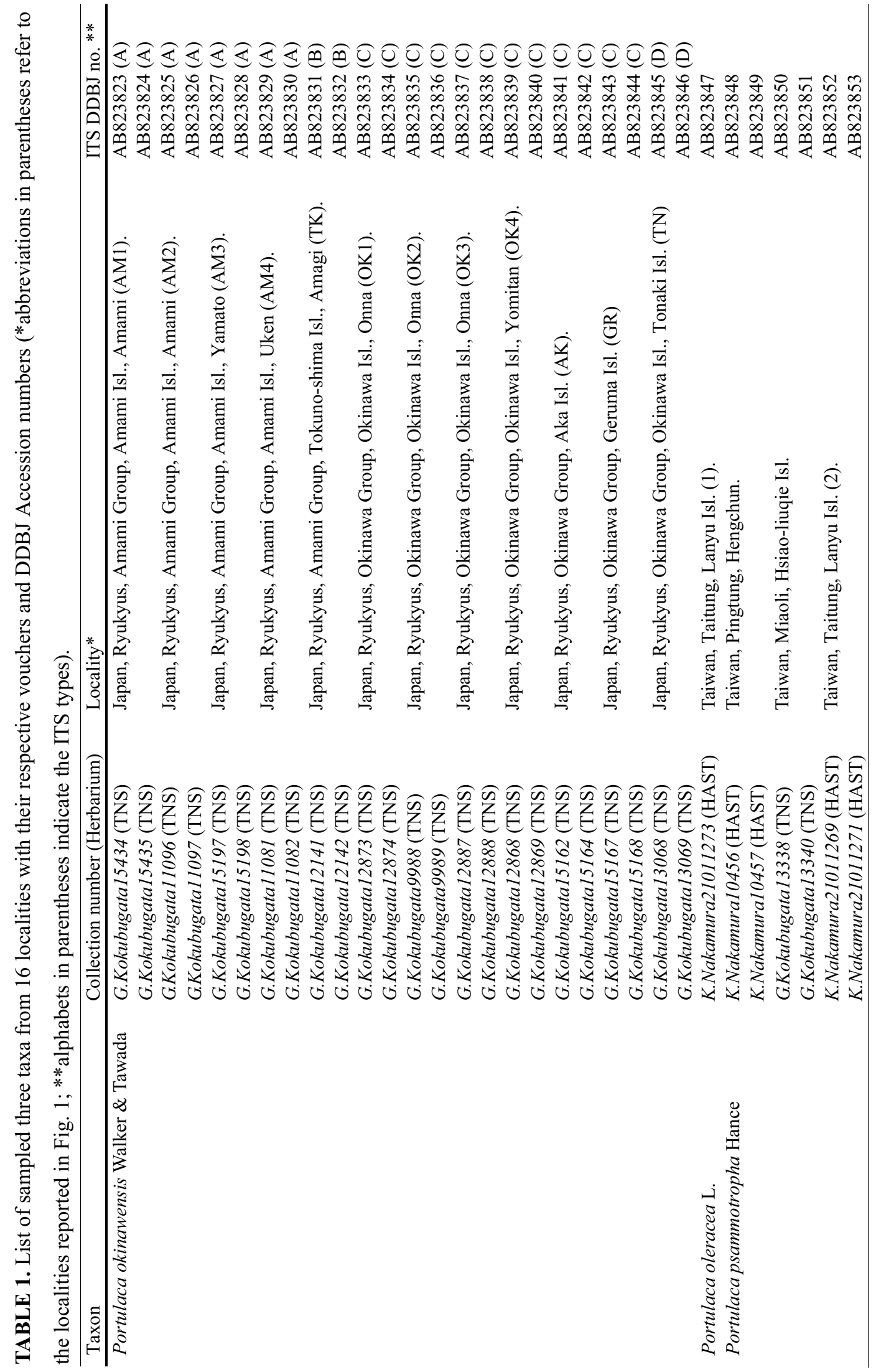


To test the phylogenetic relationship between P. okinawensis and P. pilosa subsp. pilosa, we need to incorporate many other congeners in phylogenetic analyses; we therefore utilized ITS (Internal Transcribed Spacer region of nuclear ribosomal DNA) data reported in a preceding molecular study of the genus (Ocampo $\&$ Columbus 2012). The ITS sequences of 54 Portulaca species, including P. pilosa subsp. pilosa, were obtained from GenBank (Table 2). This data set from GenBank also included P. villosa von Chammisso (1831: 565) [三 P. pilosa subsp. villosa (Cham.) Geesink (1969: 297)], which Geesink (1969) recognized as a morphologically closely related species of $P$. okinawensis. In addition, our collections of $P$. psammotropha Hance (1852: 660), distributing in southern China, southern Taiwan and the northern Philippines (Chung et al. 2008), were included in the analyses, because Walker \& Tawada (1951) recognized that this species is morphologically most similar to P. okinawensis but differs in having axillary hairs. We collected a total of 6 samples of $P$. psammotropha in three islets of Taiwan (total three localities) (Table 1). Furthermore, our collection of one plant of P. oleracea from Taiwan was included in the analyses. For outgroups, we followed preceding studies (Ocampo \& Columbus 2010, 2012) and used Talinopsis frutescens A. Gray (1852: 15; Anacampserotaceae), Pereskia aculeata Miller (1768: without pagination; Cactaceae), and Talinum paniculatum (von Jacquin 1760: 22) Gaertner (1791: 219; Talinaceae), whose ITS data were also cited from GenBank (Table 2).

Voucher specimens of our collection were deposited in the herbaria of Academia Sinica, Taipei (HAST) and the National Museum of Nature and Science, Japan (TNS).

\section{DNA extraction, amplification, and sequencing}

For DNA extraction, the DNeasy Plant Mini Kit (Qiagen, Valencia, CA, USA) was used following the manufacturer's protocols. The isolated DNA were deposited in the Molecular Biodiversity Research Center of the National Museum of Nature and Science (Japan).

The amplification of the ITS region (ITS1, 5.8S, and ITS2), was made by the polymerase chain reaction (PCR) using an iCycler (Bio-Rad, Hercules, CA, USA). The forward primer AB101 (5'-ACG AAT TCA AGG TCC GGT GAA GTG TTC G-3') and the reverse primer AB102 (5'-TAG AAT TCC CCG GTT CGC TCG CCG TTA C-3') (Douzery et al. 1999) were used for amplification. Amplifications were performed using Takara LA taq with GC buffer II (Takara, Otsu, Japan) and Ampdirect Plus buffer (Shimadzu, Kyoto, Japan). The PCR profile comprised 35 cycles of $1 \mathrm{~min}$ at $94^{\circ} \mathrm{C}, 30 \mathrm{~s}$ at $55^{\circ} \mathrm{C}$, and $1.5 \mathrm{~min}$ at $72^{\circ} \mathrm{C}$ after an initial denaturing for $3 \mathrm{~min}$ at $94^{\circ} \mathrm{C}$. The PCR products were checked by electrophoresis before purification with ExoSAP-IT (USB Corp., Cleveland, OH, USA).

The cycle sequencing was carried out with a BigDye Terminator Cycle Sequencing Kit ver. 3.1 (Applied Biosystems, Foster City, CA, USA) using PCR primers listed above with the additional internal reverse primer N2 (5'-GGC GCA ACT TGC GTT CAA-3') and the forward primer N3 (5'-GCT CTC GCA GCA TCG ATG AAG-3') designated by T. Yukawa (TNS, personal communication). The Sanger sequencing products were then purified by ethanol precipitation. Automated sequencing was carried out with an Applied Biosystems 3130xl Genetic Analyzer. The electropherograms were assembled using ATGC ver. 4.01 software (Genetyx Co., Tokyo, Japan). Sequence data from this study were deposited in the DDBJ (DNA Data Bank of Japan) databases (since 1983).

\section{Phylogenetic analyses}

The DNA sequences were aligned using ClustalW 1.8 software (Thompson et al. 1994) and then manually adjusted. Phylogenetic analyses were based on a Bayesian approach using MrBayes 3.1.2 (Ronquist \& Huelsenbeck 2003) and a maximum parsimony (MP) criterion using PAUP* version 4.0b10 (Swofford 2002). In the Bayesian phylogenetic analysis, the Hierarchical Likelihood Ratio Tests (hLRT) implemented in MrModeltest 2.2 (Nylander 2004) was used to estimate the appropriate evolutionary model of nucleotide substitutions. Based on the model selected, two separate runs of Metropolis coupled Markov chain Monte Carlo (MCMCMC) analyses were performed, each with a random starting tree and four chains (one cold and 
TABLE 2. Genebank accession numbers of ITS sequences referred from Ocampo \& Columbus (2012).

\begin{tabular}{|c|c|c|c|}
\hline Taxon & Collection number (Herbarium) & Collection area & ITS Genbank no. \\
\hline INGROUP & & & \\
\hline Portulaca amilis Speg. & Ocampo et al. 1556 (RSA, SI) & Argentina & JF508527 \\
\hline P. australis Endl. & Ocampo et al. 1747 (BRI, RSA) & Australia & JF508531 \\
\hline P. bicolor F.Muell. & Ocampo et al. 1753 (BRI, RSA) & Australia & JF508532 \\
\hline P. cf. bicolor & Ocampo et al. 1726 (BRI, RSA) & Australia & JF508530 \\
\hline P. biloba Urb. & Carter 18168 (RSA) & USA & JF508533 \\
\hline P. californica D.Legrand & Ocampo \& Columbus 1529 (RSA) & Mexico & JF508534 \\
\hline P. canariensis Danin et Reyes-Bet. & Reyes-Betancort s.n (RSA, from seed) & Canary Isl. & JF508535 \\
\hline P. confertifolia Hauman & Ocampo et al. 1619 (RSA, SI) & Argentina & JF508536 \\
\hline P. constricta M.G.Gilbert & Kilian et al. 5916 (B) & Yemen & JF508537 \\
\hline P. cryptopetala Speg. & Ocampo et al. 1540 (RSA, SI) & Argentina & JF508538 \\
\hline P. decipiens Poelln. & Ocampo et al. 1758 (BRI, RSA) & Australia & JF508539 \\
\hline P. digyna F.Muell. & Ocampo et al. 1749 (BRI, RSA) & Australia & JF508540 \\
\hline P. echinosperma Hauman & Ocampo et al. 1638 (RSA, SI) & Argentina & JF508541 \\
\hline P. elatior Mart. ex Rohrb. & Ocampo $1708 c v$ (RSA) (cult.) & Caribbean & JF508542 \\
\hline P. eruca Hauman & Ocampo et al. 1645 (RSA, SI) & Argentina & JF508543 \\
\hline P. filifolia F.Muell. & Ocampo et al. 1733 (BRI, RSA) & Australia & JF508544 \\
\hline P. foliosa Ker Gawl. & Ocampo $1772 c v$ (RSA) (cult.) & Tropical Africa & JF508546 \\
\hline P. fulgens Griseb. & Ocampo et al. 1636 (RSA, SI) & Argentina & JF508547 \\
\hline P. giliesii Hook. & Ocampo et al. 1545 (RSA, SI) & Argentina & JF508548 \\
\hline P. grandiflora Hook. & Ocampo et al. 1662 (RSA, SI) & Argentina & JF508549 \\
\hline P. grandiflora Hook. cv. & Ocampo $1403 c v(\mathrm{RSA})$ & Cultivated & JF508550 \\
\hline P. guanajuatensis G.Ocampo & Ocampo 1482 (RSA) & Mexico & JF508551 \\
\hline P. halimoides L. & Ocampo 1474 (RSA) & Mexico & JF508552 \\
\hline P. hereroensis Schinz & Roodt 223 (PRE) & Botswana & JF508554 \\
\hline P. howellii (D.Legrand) Eliasson & Jaramillo 3332 (CDS) & Galápagos Isl. & JF508555 \\
\hline P. intraterranea J.M.Black & Ocampo et al. 1748 (BRI, RSA) & Australia & JF508556 \\
\hline P. johnstonii Henrickson & Columbus 5076 (RSA) & Mexico & JF508557 \\
\hline P. lutea Sol. ex G.Forster & Morden 1575 (HAW) & Hawaii & JF508558 \\
\hline P. massaica S.M.Phillips & Cruse-Sanders s.n. (RSA) & Tanzania & JF508559 \\
\hline P. matthewsii G.Ocampo & Ocampo 1425 (RSA) & Mexico & JF508560 \\
\hline P. mexicana P.Wilson & Ocampo \& Morales 1461 (RSA) & Mexico & JF508561 \\
\hline P. molokiniensis Hobdy & Perlman 12643 (RSA) & Hawaii & JF508562 \\
\hline P. mucronulata D.Legrand & Ocampo et al. 1598 (RSA, SI) & Argentina & JF508563 \\
\hline P. oblonga Peter & Mboya $877(\mathrm{MO})$ & Tanzania & JF508564 \\
\hline P. obtusa Poelln. & Ocampo et al. 1591 (RSA, SI) & Argentina & JF508565 \\
\hline P. oligosperma F.Muell. & Ocampo et al. 1751 (BRI, RSA) & Australia & JF508579 \\
\hline P. papulifera D.Legrand & Ocampo et al. 1569 (RSA, SI) & Argentina & JF508580 \\
\hline P. perennis R.E.Fr. & Ocampo et al. 1606 (RSA, SI) & Argentina & JF508581 \\
\hline P. pilosa $\mathrm{L}$. & Nortrup s.n. (UNCC) & USA & JF508585 \\
\hline P. pusilla Kunth & Gröger 927 (MO) & Venezuela & JF508587 \\
\hline P. quadrifida $\mathrm{L}$. & Cruse-Sanders s.n. (RSA) & Tanzania & JF508588 \\
\hline$P$. retusa Engelm. & Baker 16325 (ARIZ) & USA & JF508590 \\
\hline P. rotundifolia R.E.Fr. & Ocampo et al. 1611 (RSA, SI) & Argentina & JF508591 \\
\hline P. rubricaulis Kunth & Simá et al. $2433(\mathrm{MO})$ & Mexico & JF508592 \\
\hline P. rzedowskiana G.Ocampo & Ocampo 1124 (IEB) & Mexico & JF508593 \\
\hline P. sclerocarpa A.Gray & Morden 1828 (HAW) & Hawaii & JF508594 \\
\hline P. smallii P.Wilson & Herkenham s.n. (UNCC) & USA & JF508595 \\
\hline P. suffrutescens Engelm. & Ocampo \& Columbus 1505 (RSA) & Mexico & JF508597 \\
\hline P. tingoensis J.F.Macbr. & Ocampo et al. 1615 (RSA, SI) & Argentina & JF508598 \\
\hline $\begin{array}{l}\text { P. trituberculata Danin, Domina et } \\
\text { Raimondo }\end{array}$ & Danin \& Domina SC55 (PAL; RSA from seed) & Italy & JF508574 \\
\hline P. tuberosa Roxb. & Ocampo et al. 1737 (BRI, RSA) & Australia & JF508599 \\
\hline P. villosa Cham. & Perlman 13305 (PTBG) & Hawaii & JF508604 \\
\hline P. wightiana Wall. ex Wight et Arn. & Burgoyne 3613 (PRE) & Namibia & JF508605 \\
\hline $\begin{array}{l}\text { P. yecorensis Henrickson et T.Van } \\
\text { Devender } \\
\text { OUTGROUP }\end{array}$ & Columbus 5006 (RSA) & Mexico & JF508606 \\
\hline Pereskia aculeata Mill. (Cactaceae) & $N A$ (ZSS) (cult.) & Americas & JF508526 \\
\hline Talinopsis frutescens A.Gray (Montiaceae) & Ocampo 1480 (RSA) & Mexico & JF508607 \\
\hline $\begin{array}{l}\text { Talinum paniculatum (Jacq.) Gaertn. } \\
\text { (Talinaceae) }\end{array}$ & Ocampo \& Morales 1458 (RSA) & Mexico & JF508608 \\
\hline
\end{tabular}


three heated). The MCMCMC length was one million generations, and the chain was sampled every one hundredth generation from the cold chain. The first 2500 sample trees (25\% of the total 10000 sample trees) were discarded as burn-in after checking that the average standard deviation of split frequencies (ASDSF) reached a stationary state at $<0.01$ thereafter. As a guide to convergence, the potential scale reduction factors (PSRFs) were ascertained to be reasonably close to 1.0 for all parameters in an output table. A 50\% majority consensus tree of the output tree file from MrBayes was generated by TREEVIEW (Page 1996).

In the MP phylogenetic analysis, indels were treated as missing data. The characters were treated as unordered, and the character transformations were equally weighted. The branch collapse option was set to collapse at a minimum length of zero. A heuristic parsimony search was performed with 200 replicates of random additions of sequences with ACCTRAN character optimization, tree bisection-reconnection (TBR) branch swapping, and MULTREES and STEEPEST DESCENT options on. Statistical support for each clade was assessed by bootstrap analysis (Felsenstein 1985). Ten thousand replicates of heuristic searches, with the TBR branch swapping switched on and MULTREES options off, were performed to calculate bootstrap values (BS).

\section{Intraspecific morphological comparison}

The following morphological characters of P. okinawensis were examined: number of stigma lobes and stamens, color and shape of petals, and color of stems. The number of stigma lobes and stamens was studied fixing the materials in the FAA solution, while the color and shape of the petals and stems were observed in living plants. A total of 46 samples were examined: 11 plants from Amami Island (4 localities), 5 plants from Tokuno-shima Island (1), 22 plants from Okinawa Island (4 including the locus classicus of P. okinawensis), 3 plants from Aka Island (1), 3 plants from Geruma Island (1), and 2 plants from Tonaki Island (1) (Table 3). The equality of variances for the number of the stigma lobes and stamens between the Amami Islands and the Okinawa Islands was firstly evaluated using the $F$-test. If the $F$-test shows equal variances, the Student's $t$-test is applied; if $F$-test shows no equal variances, the Student's t-test with Welch's correction is applied.

The color of the stems was examined in 79 samples from Amami Island (31 plants from 4 localities) and Tokuno-shima Island (5 from 1), Okinawa Island (28 from 4, holotype included), Aka Island (5 from 1), Geruma Island (5 from 1), and Tonaki Island (5 from 1). The on-line herbarium database of the National Museum of Natural History, Smithsonian (2013) was checked for the holotype.

\section{Results}

\section{Phylogenetic relationships based on ITS}

Four ITS types were found in P. okinawensis: type A in plants collected from Amami Island; type B in plants from Tokuno-shima Island; type $\mathrm{C}$ in plants from Okinawa Island, Aka Island, and Geruma Island; type D in plants from Tonaki Island. The ITS sequences were identical in the 6 plants of $P$. psammotropha collected from 3 localities of Taiwan, and differed from the four ITS types of $P$. okinawensis. The ITS sequence of $P$. oleracea was also different from those of $P$. okinawensis and P. psammotropha. For these three species, we used ITS types as operational taxonomic units (OUTs) in the Bayesian and MP phylogenetic analyses. Finally we obtained 63 OUTs, including six ITS types of the three species obtained herein, 54 accessions as ingroups and three outgroup accessions obtained from GenBank. After alignment of the 63 OUTs, we obtained a matrix of $650 \mathrm{bp}$.

The model of GTR $+\mathrm{I}+\mathrm{G}$ was selected in the Bayesian analysis. The $50 \%$ majority rule consensus tree of all the post-burn-in trees is depicted with Bayesian posterior probabilities (PPs, Fig. 2). In the MP analysis, 233 of 350 variable characters were parsimony informative in the ITS matrix including the outgroup taxa. 3838 equally most parsimonious trees of 884 steps were obtained with a consistency index (CI) of 0.632 , a retention index (RI) of 0.804 , and a rescaled consistency index (RC) of 0.501 . The topology of the strict consensus tree was highly compatible with that of the Bayesian tree, and thus bootstrap percentages (BPs) are plotted on the Bayesian tree (Fig. 2). 


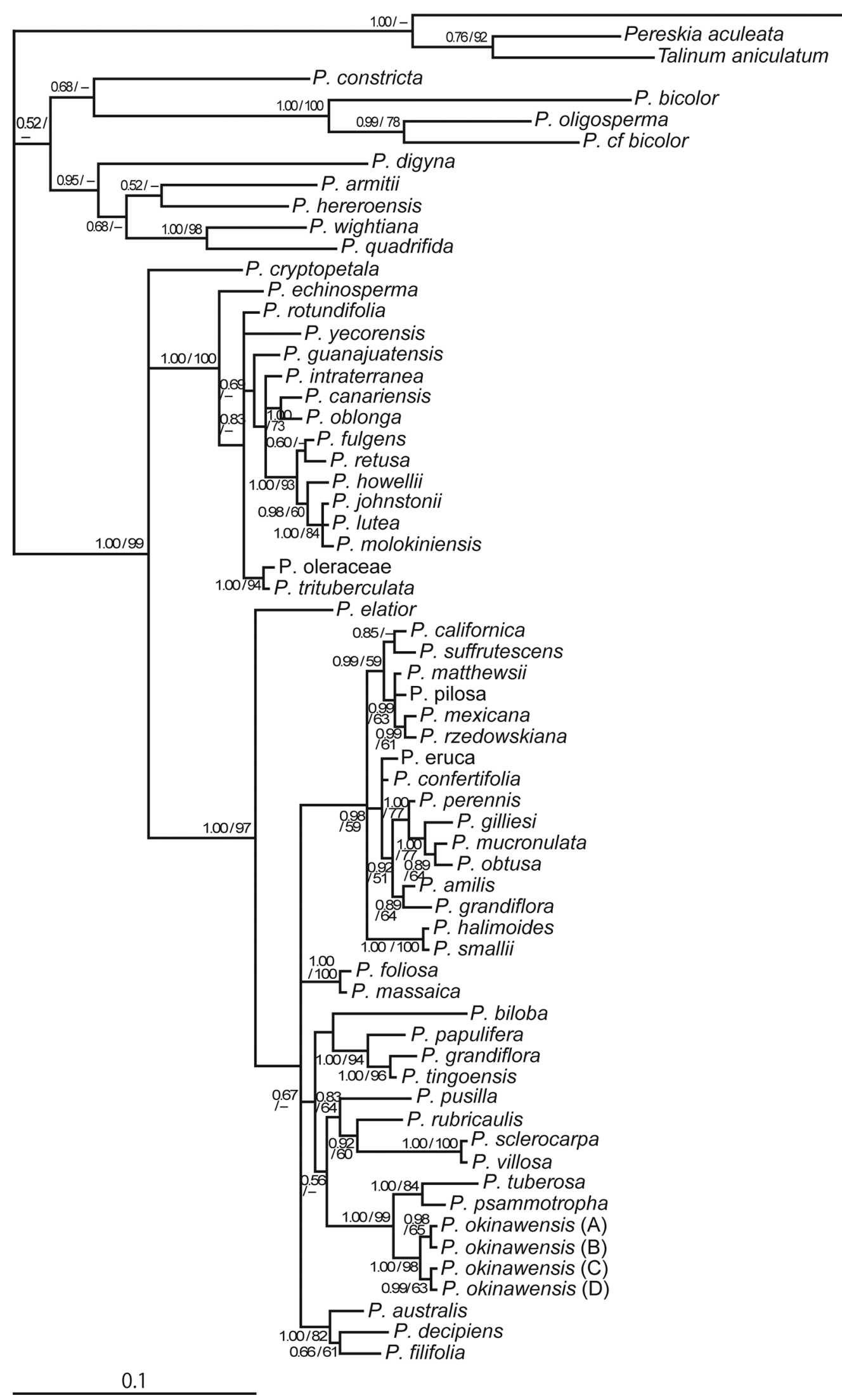

Talinopsis frutescens

FIGURE 2. Bayesian phylogenetic tree for 60 OTUs of Portulaca with three outgroups based on internal transcribed spacer (ITS) sequence. The topology of the maximum parsimony (MP) strict consensus tree was highly compatible with the Bayesian tree. Bayesian posterior probabilities (left) and bootstrap percentages in the MP analysis (right) are shown [see the Table 1 for the localities collection of the four ITS types (A-D) of P. okinawensis]. 
Both the Bayesian and MP analyses (Fig. 2) demonstrated that four ITS types of $P$. okinawensis formed a well-supported clade (PP / BS $=1.00 / 98 \%$ ) including two subclades: the first one comprises the type A (plants from Amami Island) and the type B (plants from Tokuno-shima Island) (0.98 / 65\%), while the other group comprises the type $\mathrm{C}$ (plants from Okinawa, Aka, and Geruma Islands) and the type D (plants from Tonaki Island) (0.99 / 63\%). A sister clade of P. okinawensis includes P. psammotropha and P. tuberosa Roxb. On the other hand, P. okinawensis and P. pilosa subsp. pilosa were intervened by many species in the phylogeny and they were not closely related with each other. Portulaca okinawensis and P. villosa (三 P. pilosa subsp. villosa) were comparatively closely related but fell into two different well-supported clades.

\section{Morphological characters}

The number of stamens ranged from 12 to 32 in P. okinawensis (Table 3). In the plants from the Amami Islands, the stamens were 12-15, while in those from the Okinawa Islands were 14-32. The $F$-test showed that the variances in the number of the two island groups were not statistically equal $(p<0.0001)$, and the Student's $t$-test with Welch's correction was applied. The test showed that there was a significant statistic difference between the two island groups $(p<0.0001)$.

The number of stigma lobes was 3-4 in P. okinawensis (Table 3). The $F$-test showed that the variances of the two island groups were statistically equal, and the Student's $t$-test was applied. The test showed that there was no significant difference between the two island groups.

The plants collected from the Amami Islands had bright-green stems (Fig. 3A-C); while those from the Okinawa Islands had reddish-green stems (Fig. 3D-H). Petals of the plants from the Amami Islands were lemon-colored (Fig. 3A-C). Those from the Okinawa Islands were orange-yellow (Fig. 3D-H). Moreover, the plants collected from Amami (Fig. 3A \& B), Tokuno-shima (Fig. 3C), Aka (Fig. 3H) and Geruma islands had the petal obovate, while the plants from Okinawa (Fig. 3D-F) and Tonaki (Fig. 3G) islands had nallowly obovate to oblanceolate petals.

The colors of stems and petals of the holotype (S. Tawada 2221) were degraded and not observable and not written on the description of $P$. okinawensis (Walker \& Tawada 1951). However, there was a hand-written note indicating that petal color of the holotype was orange-yellow, and its stem color was reddish on the specimen sheet.

TABLE 3. Comparison of number of stigma lobes and stamens of Portulaca okinawensis from the Ryukyus of Japan.

\begin{tabular}{llllll}
\hline \multirow{2}{*}{ Island group } & Island & $\begin{array}{l}\text { Locality } \\
\text { abbreviation* }\end{array}$ & $\begin{array}{l}\text { Plant sample } \\
\text { number }\end{array}$ & $\begin{array}{l}\text { Number of stigma lobe } \\
\text { (avg.) }\end{array}$ & $\begin{array}{l}\text { Number of stamen } \\
\text { (avg.) }\end{array}$ \\
\hline Amami Islands & Amami & AM1 & 4 & $4(4.0)$ & $12-15(14.3)$ \\
& & AM2 & 3 & $3(3.0)$ & $12-15(14.0)$ \\
& & AM3 & 2 & $3-4(3.5)$ & $12-15(13.5)$ \\
& & AM4 & 2 & $3(3.0)$ & $12(12.0)$ \\
& Tokuno-shima & TK & 5 & $4(4.0)$ & $12-15(12.6)$ \\
& Okinawa & OK1 & 4 & $3-4(3.3)$ & $23-24(24.7)$ \\
& & OK2 & 3 & $3-4(3.5)$ & $24-26(24.7)$ \\
& & OK3 & 6 & $3-4(3.3)$ & $23-26(24.0)$ \\
& Aka & OK4 & 9 & $3-4(3.1)$ & $15-24(19.9)$ \\
& Geruma & GK & 3 & $3-4(3.7)$ & $14-20(16.7)$ \\
& Tonaki & TN & 2 & $3(3.0)$ & $15-25(18.3)$ \\
\hline
\end{tabular}

\footnotetext{
* Refer Table 1 and Fig. 1.
} 

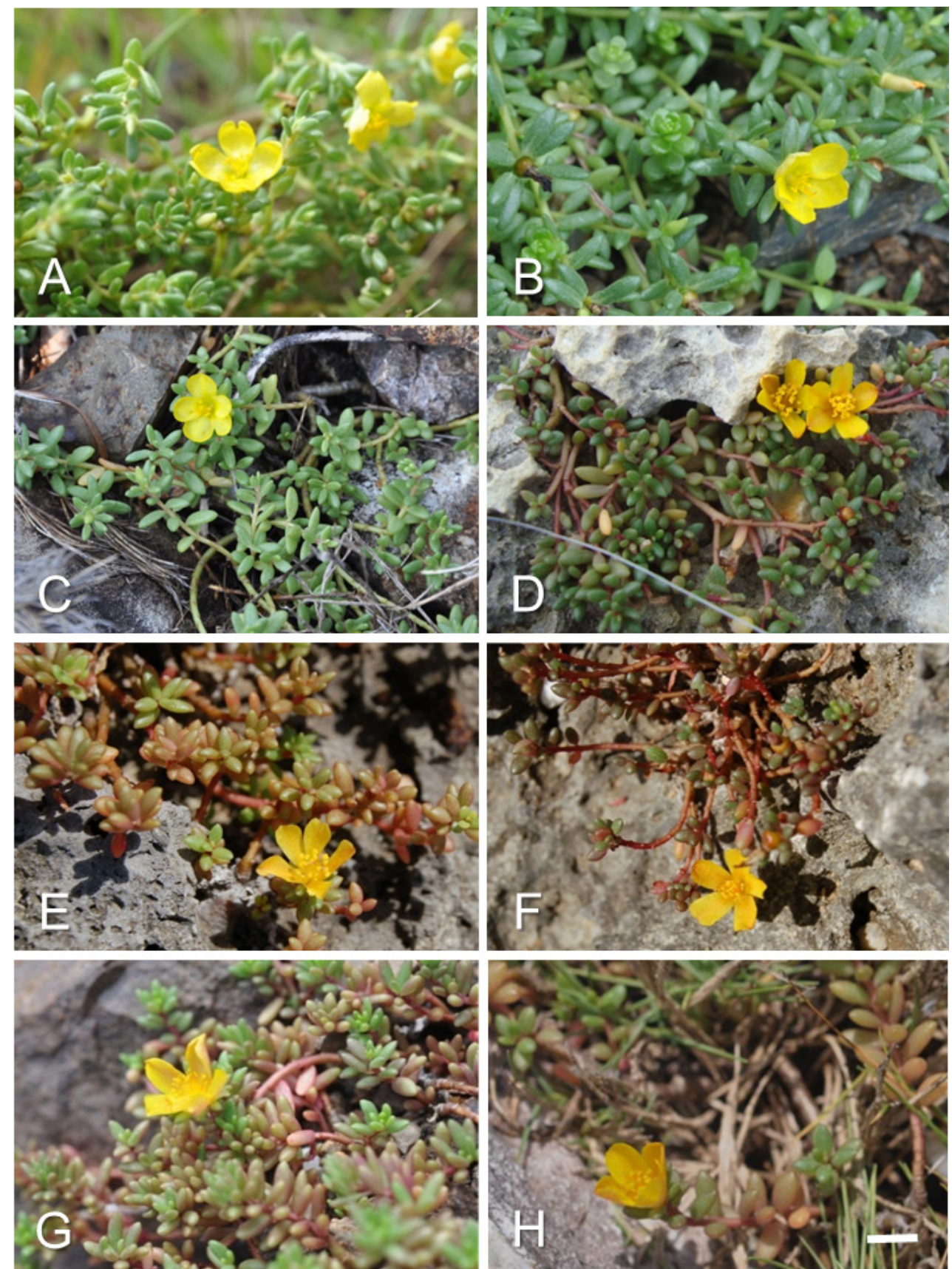

FIGURE 3. Flowering plants of Portulaca okinawensis from the Ryukyus. A. Amami Island (AM1). B. Amami Island (AM3). C. Tokuno-shima Island. D. Okinawa Island (OK1). E. Okinawa Island (OK2). F. Okinawa Island (OK4). G. Tonaki Island (TK). H. Aka Island (AK). Scale bar in $\mathrm{H}$ also applies to $\mathrm{A}-\mathrm{G}$, and indicates $5 \mathrm{~mm}$ (see the Table 1 for the localities abbreviations).

\section{Discussion}

\section{Taxonomic reconsideration of Portulaca okinawensis}

Our molecular analysis results disagree with Geesink (1969) showing that $P$. okinawensis are not closely related to $P$. pilosa subsp. pilos $a$ and it cannot be treated at subspecies rank of $P$. pilosa and revealing that $P$. okinawensis and P. villosa ( $\equiv$ P. pilosa subsp. villosa) are not conspecific.

Portulaca okinawensis is instead phylogenetically related to P. psammotropha (sensu Chung et al. 2008) collected from islets of southern Taiwan and P. tuberosa distributed from India, through Malesia, to Christmas Island of Australia (Puy et al. 1993). However, P. okinawensis is morphologically distinguishable from these 
two species by the absence of axillary hairs (Puy et al. 1993, Chung et al. 2008). Therefore, the present molecular data and morphological difference support the taxonomic concept of Walker \& Tawada (1951) treating $P$. okinawensis as an independent endemic species to the central Ryukyus.

\section{Intraspecific taxonomy of Portulaca okinawensis}

From the morphological point of view, the two subclades of $P$. okinawensis (from the Amami Islands, and from the Okinawa Islands), include plants clearly different. The plants from the Amami Islands have brightgreen stems and lemon-colored petals, while plants from the Okinawa Islands have reddish-green stems and orangey-yellow petals as same as the holotype (S. Tawada 2221). Although the ranges of the number of stigmas were slightly overlapped between the two groups, the numbers of the former are always less than 20, and are significantly different from the other. The number of stamens is 25 in the holotype (Walker \& Tawada 1951) and this is included in the ranged for the plants from the Okinawa Islands.

We conclude that the plants from the Amami and Okinawa islands should be treated as different taxonomic entities. A new variety is described below.

\section{Taxonomic treatment}

\section{A diagnostic key of Portulaca okinawensis and the related species follows:}

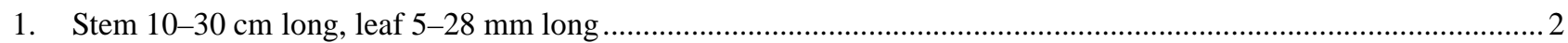

- $\quad$ Stem ca. $10 \mathrm{~cm}$ long, leaf 5-8 mm long …………............................................................................. 3

2. Leaf obovate to liner, axillary hair up to $12 \mathrm{~mm}$ long, petal white, pink, or pink with a white base, fruit 3-4 mm long

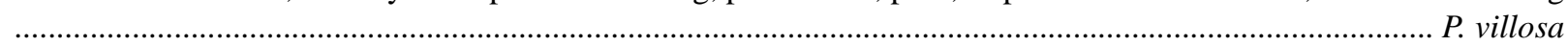

Leaf elliptic to liner, axillary hair up to $6 \mathrm{~mm}$ long, petal reddish violet or pink, fruit 5-6 mm long. .......... P. pilosa

3. Axillary hairs present ............................................................................................................ P. psammotropha

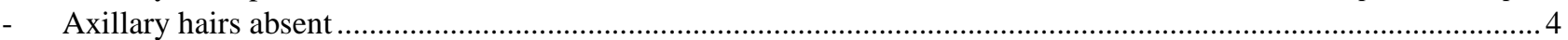

4. Number of stamens mostly more than 20, petals orange yellow, mostly obovate to nallowly obovate, stems reddish green P. okinawensis var. okinawensis

- Number of stamens less than 20, petals lemon-colored, obovate to oblanceolate, stems bright green .. okinawensis var. amamiensis

\section{Portulaca okinawensis Walker \& Tawada var. okinawensis}

Type:-JAPAN. The Ryukyus, the Okinawa Islands, Okinawa Island, Onna, 2 October 1949, Tawada 2221 (holotype US!; available from: http://collections.mnh.si.edu/search/botany/?ti=3).

Description:-Herbs perennial, 3-5 cm tall. Stems not articulated, diffuse, branched basally, ca. $1 \mathrm{~mm}$ thick; basal stems woody, prostrate, upper stems herbaceous, upright, reddish green. Root fleshy, much-branched. Leaves spirally arranged to alternate, subsessile, without axillary hairs; leaf blade $2-3 \mathrm{~mm}$ thick, oblong to obovate, 5-8 mm long, base obtuse, apex obtuse or rounded. Flowers solitary, about 10-15 mm in diameter. Sepals 2, ovate-deltate, about $2 \mathrm{~mm}$ long. Petals 5, obovate to nallowly obovate, orangey yellow, mostly without margins overlapping. Stamens 12-15. Ovary ovoid. Stigma usually trilobed or tetralobed; capsule glossy, 2-4 mm long, 2-3 mm wide.

Distribution and habitat:-The Ryukyus, the Okinawa Islands, Okinawa, Aka, Geruma, Tonaki islands. Coastal rocky slopes, xeric, saline, and exposed to direct sunlight. Portulaca okinawensis has also been recorded from Aka, Geruma, Yakabi, Tonaki, Aguni, and Kume islands of the Okinawa Islands (Shinjo \& Shinzato 2006). We have not collected samples from these islands. We examined a herbarium specimen of $P$. okinawensis collected from Yakabi Island (Miyagi 8414, RYU, collected in 1978) but we could not identify it at variety level because of the difficulty in counting of the number of stamens and the discoloring of the petals and stems.

Additional specimens examined:-JAPAN. The Ryukyus, the Okinawa Islands: Okinawa Island, Onna (OK1), 10 August 2010, Kokubugata 12873-12878 (TNS); Okinawa Island, Onna (OK2), 20 
September 2007, Kokubugata 9988, 9989, 10018 (TNS); Okinawa Island, Onna (OK3), 1 September 2010, Kokubugata 12886-12891 (TNS); Okinawa Island, Yomitan (OK4), 29 August 2010, Kokubugata 1286712872, 12879-12885 (TNS); Aka Island, 30 August 2012, Kokubugata 15161-15165 (TNS); Geruma Island, 30 August, 2012, Kokubugata 15166-15170 (TNS); Tonaki Island, 31 August 2012, Kokubugata 1517915183 (TNS).

Portulaca okinawensis Walker \& Tawada var. amamiensis Kokubugata, Koh Nakam. \& Yokota, var. nov.

Type:-JAPAN. The Ryukyus, the Amami Islands, Amami Island, Yamato, 6 September 2012, Kokubugata 15198 (holotype TNS!).

Diagnosis:-Differt a var. okinawensi staminibus 12-15, petalis citrinis, obovatis vel oblanceolatis, caulibus viridibus.

Description:-Herbs perennial, 3-5 cm tall. Stems not articulated, diffuse, branched basally, ca. $1 \mathrm{~mm}$ thick; basal stems woody, prostrate, upper stems herbaceous, upright, bright green. Root fleshy, much-branched. Leaves spirally arranged to alternate, subsessile, without axillary hairs; leaf blade $2-3 \mathrm{~mm}$ thick, oblong to obovate, 5-8 $\mathrm{mm}$ long, base obtuse, apex obtuse or rounded. Flowers solitary, about 10-15 $\mathrm{mm}$ in diameter. Sepals 2, ovate-deltate, about $2 \mathrm{~mm}$ long. Petals 5, obovate, emarginate, rotund to obtuse, lemon-colored, with margins overlapping. Stames 12-15. Ovary ovoid. Stigma usually trilobed or tetralobed; capsule glossy, 2-4 mm long, 2-3 mm wide.

Etymology:-The epithet refers to the Amami Islands, the locus classicus.

Distribution and habitat:-Endemic to the Amami Islands (the Ryukyus), in Amami and Tokuno-shima islands. Coastal rocky slopes, xeric, saline, and exposed to direct sunlight. In Kakeroma Island, being an islet situated in the Amami Island, P. okinawensis has been recorded. However, we could not obtain and investigate samples from the island.

IUCN Red list category:- It can be included in the Data Deficient (DD) category of IUCN Red List categories (IUCN 2010) as there are inadequate information to make a direct or indirect assessment of its risk of extinction based on its distribution and/or population status.

Additional specimens examined (paratypes):- JAPAN. The Ryukyus, the Amami Islands: Amami Island, Amami (AM1), 3 November 2010, Kokubugata 12939-12942, 7 September 2012, Kokubugata 15434-15443 (TNS); Amami (AM2), 18 October 2008, Kokubugata 11096-11100 (TNS); Yamato (AM3), 6 September 2012, Kokubugata 15197-15202; Uken (AM4), 18 October 2008, Kokubugata 11081-11085, 11102 (TNS); Tokuno-shima Island, Amagi (TK), 17 October 2007, Kokubugata 12140-12144 (TNS).

\section{Acknowledgments}

We thank D. Iamonico for valuable comments; and A. Abe, C.-I Huang, Y. Minemoto, C.-I Peng, M. Tabata and H. Yamashita for assistance in field surveys. This study was carried out under the project of Grant-in-Aid for Scientific Research (B) (JSPS KAKENHI Grant Number 25290085) and that of "Elucidative studies of delimitation and origin on endemic and narrow-range species in Japan" managed by the National Museum of Nature and Science, Japan, and supported in part by the Mitsui \& Co., Ltd. Environment Fund (No. RC10-C097).

\section{References}

Akiyama, S. (2006) Portulacaceae. In: Iwatsuki, K., Boufford, D.E. \& Ohba, H. (eds.) Flora of Japan 2a. Kodansha, Tokyo, pp. 181182.

Chammisso, L.K.A. von (1831) Portulacaceae. In: von Driesen, L. (ed.) Beitrag zur Kenntnifs der Varietäten nud Bastardformen einheimischer Gewächese. Linnaea 6: 484-592.

Chung, S., Madulid, D.A. \& Hsu, T. (2008) Portulaca psammotropha Hance (Portulacaceae), a neglected species in the flora of Taiwan and the Philippines. Taiwania 53: 90-95. 
DDBJ (since 1983) DNA Data of Bank of Japan, National Institute of Genetics, Japan, Mishima. Available from: http:// www.ddbj.nig.ac.jp/ (accessed: 6 June 2013).

Douzery, E.J.P., Pridgeon, A.M., Kores, P., Linder, H.P., Kurzweil H. \& Chase, M.W. (1999) Molecular phylogenetics of Diseae (Orchidaceae): a contribution from nuclear ribosomal ITS sequences. American Journal of Botany 86: 887-899. http://dx.doi.org/10.2307/2656709

Felsenstein, J. (1985) Confidence limits on phylogenies: an approach using the bootstrap. Evolution 39: 783-791. http://dx.doi.org/10.2307/2408678

Gaertner, J. (1791) De Fructibus et Seminibus Plantarum 2. Schrammii, Tübingen, 352 pp.

Geesink, T. (1969) An account of the genus Portulaca in Indo-Australia and the Pacific (Portulacaceae). Blumea 17: $276-301$.

Gray, A. (1852) Plantae Wrightianae. Smithsonian Contributions to Knowledge 3: 1-146.

Hance, H.F. (1852) Portulacaceae. In: Walpers, G. G. (ed) Annales Botanices Systematicae 2. Friedrich Hofmeister, Leipzig, p. 660.

Hatusima, S. (1975) Flora of the Ryukyus, added and corrected edition. Okinawa Association of Biology Education, Naha, 1002 pp.

Hatusima, S. \& Amano, T. (1994) Flora of the Ryukyus, South of Amami Island, second edition. Biological Society of Okinawa, Nishihara, $391 \mathrm{pp}$.

Hotta, M. (2004) Distribution areas of rare or endangered plant species in Amami Island. Bulletin of the Kagoshima Prefectural Colleague 55: 1-108.

IUCN (2010) The IUCN Red list of the threatened species, version 2010.4. Available from: http://www.iucnredlist.org (accessed: 2 June 2013).

Jacquin, N. J. von (1760) Enumeratio Systematica Plantarum, quas in Insulis Caribaeis. Inter Documentation Company AG, Zug, 41 $\mathrm{pp}$.

Japanese Ministry of Environment (2012) Red Data List (Plants). Available from: http://www.biodic.go.jp/rdb/rdb_f.html. (accessed: 3 January 2013).

Linnaeus, C. (1753) Species Plantarum 1. Laurentii Salvii, Holmiae, 560 pp.

Linnaeus, C. (1767) Systema Naturae $12^{\text {th }}$ ed. 2. Laurentii Salvii, Holmiae,735 pp.

Miller, P. (1768) The Gardener's Dictionary 8th ed. Printed for the author, London, without pagination.

Momiyama, Y. (1982) Portulacaceae. In: Satake, Y., Ohwi, J., Kitamura, S., Watari, S. \& Tominari, T. (eds.) Wild Flowers of Japan 2. Heibonsha, Tokyo, pp. 31.

National Museum of Natural History, Smithsonian (2013). Search the Botany Collections. Smithsonian National Museum of Natural History, Washington, D.C. Available from: http://collections.mnh.si.edu/search/botany/?ti=3 (accessed: 23 March 2013).

Nylander, J.A.A. (2004) MrModeltest ver2. Distributed by the author. Evolutionary Biology Centre, Uppsala University.

Nyffeler, R. \& Eggli, U. (2010) Disintegrating Portulacaceae: a new familial classification of the suborder Portulacineae (Caryophyllales) based on molecular and morphological data. Taxon 59: 227-240.

Ocampo, G. \& Columbus, J.T. (2010) Molecular phylogenetics of suborder Cactineae (Caryophyllales), including insights into photosynthetic diversification and historical biogeography. American Journal of Botany 97: 1827-1847. http://dx.doi.org/10.3732/ajb.1000227

Ocampo, G. \& Columbus, J.T. (2012) Molecular phylogenetics, historical biogeography, and chromosome number evolution of Portulaca (Portulacaceae). Molecular Phylogenetics and Evolution 63: 97-112. http://dx.doi.org/10.1016/j.ympev.2011.12.017

Page, R.D.M (1996) TREEVIEW: An application to display phylogenetic trees on personal computers. Computer Applications in the Bioscience 12: 357-358.

PIER-Pacific Island Ecosystems at Risk (2013) Portulaca pilosa. Available from: http://www.hear.org/pier/species/ portulaca_pilosa.htm (accessed: 19 February 2013).

Puy, D.J.D., Telford, I.R.H. \& Orchard, A.E. (1993) Portulacaceae. In: George, A.S., Orchard, A.E. \& Hewson, H.J. (eds.) Flora of Australia 50. AGPS Press Publication, Canberra, pp. 118-121.

Ronquist, F. \& Huelsenbeck, J.P. (2003) MrBayes 3: Bayesian phylogenetic inference under mixed models. Bioinformatics 19: 15721574. http://dx.doi.org/10.1093/bioinformatics/btg180

Shimabuku, K. (1997) Check List Vascular Flora of the Ryukyu Islands, revised edition. Kyushu University Press, Fukuoka, 855 pp.

Shinjo, K. \& Shinzato, T. (2006) Portulaca okinawensis Walker et Tawada. In: Okinawa Prefecture (ed.) Red Data Okinawa, revised version. Okinawa Prefecture, Naha, p. 72.

Swofford, D.L. (2002) PAUP: phylogenetic analysis using parsimony, version 4.0b10. Sinauer Associates, Sunderland.

Thompson, J.D., Higgins, D.G. \& Gibson, T.J. (1994) CLUSTAL W: improving the sensitivity of progressive multiple sequence alignment through sequence weighting, position specific gap penalties and weight matrix choice. Nucleic Acids Research 22: 4673-4680. http://dx.doi.org/10.1093/nar/22.22.4673

Walker, E.H. (1976) Flora of Okinawa and the southern Ryukyu Islands. Smithsonian Institution Press, Washington, 1159 pp.

Walker, E.H. \& Tawada, S. (1951) A new species of Portulaca from Okinawa. Journal of the Washington Academy of Sciences 41: 138. 